\title{
Effect of Astaxanthin Supplementation on Semen (Karan Fries Bulls) Storage at $5^{\circ} \mathrm{C}$
}

\author{
Simson Soren*, Sohan Vir Singh and Sunil Kumar \\ Animal Physiology Division, Climate Resilient Livestock Research Centre, \\ Indian Council of Agricultural Research-National Dairy Research Institute (ICAR-NDRI), \\ Karnal (Haryana)-132001, India \\ *Corresponding author
}

\begin{tabular}{|c|c|}
\hline & A B S T R A C T \\
\hline & \multirow{6}{*}{$\begin{array}{l}\text { Astaxanthin (AX) is a xanthophyll carotenoid having the powerful antioxidant ability with } \\
\text { much beneficial health effects. The present study was conducted to observe the effect of } \\
\text { AX on sperm quality of Karan Fries (Tharparkar X Holstein Friesian) bulls during storage } \\
\text { at } 5{ }^{\circ} \mathrm{C} \text {. The neat semen was diluted with Tris egg yolk citric acid fructose (TEYCAF) } \\
\text { extender and equally divided into two parts, i.e. control and AX supplementation. The } \\
\text { percentage of progressive motility at } 0,24,48 \text { and } 72 \text { hours were } 78.75 \pm 1.25 \text { vs. } 78.75 \pm \\
1.25 ; 77.50 \pm 1.44 \text { vs. } 72.5 \pm 2.5 ; 77.50 \pm 1.44 \text { vs. } 71.25 \pm 1.25 \text { and } 68.75 \pm 1.25 \text { vs. } 66.25 \\
\pm 2.39 \text { in AX supplemented vs. control, respectively. The percentage of live spermatozoa } \\
\text { at } 0,24,48 \text { and } 72 \text { hours were as } 88.69 \pm 0.09 \text { vs. } 88.12 \pm 1.32 ; 85.93 \pm 0.59 \text { vs. } 83.76 \pm \\
0.61 ; 82.95 \pm 1.31 \text { vs. } 78.57 \pm 0.70 \text { and } 80.92 \pm 1.26 \text { vs. } 74.07 \pm 0.95 \text { in AX supplemented } \\
\text { vs. control, respectively. The concentration of catalase (CAT) enzyme in supernatant was } \\
\text { reduced (p<0.05) in AX supplemented sample at } 48 \text { ( } 7.38 \pm 1.43 \text { vs. } 14.62 \pm 2.03 \text { ) and } 72 \\
(14.43 \pm 1.29 \text { vs. } 19.45 \pm 2.82 \text { ) hours. The superoxidase dismutase (SOD) concentration } \\
\text { was lowered (p<0.05) only at } 24 \text { hours of preservation in AX supplemented samples than } \\
\text { control. It can be concluded from the study that supplementation of AX to the semen } \\
\text { extender assisted in maintaining or protecting the spermatozoa from damage during } \\
\text { storage at } 5{ }^{\circ} \mathrm{C} \text {. }\end{array}$} \\
\hline Keywords & \\
\hline $\begin{array}{l}\text { Astaxanthin, } \\
\text { Semen, Storage, } \\
\text { Refrigerator } \\
\text { temperature. }\end{array}$ & \\
\hline Article Info & \\
\hline $\begin{array}{l}\text { Accepted: } \\
\text { 04 April } 2017 \\
\text { Available Online: } \\
10 \text { May } 2017\end{array}$ & \\
\hline & \\
\hline
\end{tabular}

\section{Introduction}

Astaxanthin $(\mathrm{AX})$ is the major colourful pigments of seafood, i.e. salmon, trout, red sea bream, shrimp, lobster etc. Several studies revealed the beneficial health effect of $A X$ as photoprotectants, eye health, antiinflammatory, improvement of immunity and other important application in nutraceuticals, cosmetics, food and feed industries (Yuan et al., 2011; Ciapara et al., 2006; Guerin et al., 2003). Due to its various health beneficial properties, commercially natural $\mathrm{AX}$ is cultivated from Haematococcus Pluvialis (richest source), which can accumulate higher amount of astaxanthin under stressful conditions (Wayama et al., 2013). AX is more powerful antioxidant than beta-carotene and lutein (O'Connor and O'Brien, 1998) enhancing antibody production (Jyonouchi et al., 1994) as well as boosts mitochondrial activity (Wolf et al., 2010). The supplementation of AX @ 2 and $4 \mu \mathrm{M}$ shown to increase sperm vitality and plasma 
membrane integrity $(\mathrm{p} \leq 0.05)$ in rams diluted semen during the storage period of 72 hours at $5{ }^{\circ} \mathrm{C}$ (Fang et al., 2015). Malondialdehyde (product of lipid peroxidation) and reactive oxygen species (ROS) levels also decreased $(\mathrm{p} \leq 0.05)$ markedly during $72 \mathrm{hrs}$ of storage at 5 C (Fang et al., 2015). Sperm membrane is prone to free radical attack due to the high content of phospholipids (Almbro et al., 2011). As the sperm cells are the highly active cell (motile), generation of reactive oxygen (ROS) species is common and maintenance of ROS level depends upon the seminal antioxidant defense mechanism. Higher concentration of ROS damages the sperm membrane, DNA, lipid and proteins resulted in compromise fertilizing capacity of spermatozoa. Therefore, the addition of exogenous antioxidant improves the vitality and motility of spermatozoa (Sariozkan et al., 2014). One of the important features of AX is the ability to penetrate biological membranes with a protective effect of lipid peroxidation inside and outside of cell membrane (Goto et al., 2001). Supplementation of antioxidant suggested to a safe way to improve the semen quality and fertility (Eskenazi et al., 2005). Oral supplementation of AX shown to decrease the ROS and secretion of inhibin B (by Sertoli cells) indicating a positive effect on sperm functions and fertility (Comhaire et al., 2005). AX was shown to have the chemoprotective potential against cyclophosphamide-induced germ cell toxicity in mice reported by Tripathi and Jena (2008).

During cryopreservation, lipid membrane of spermatozoa prone to free radical attack due to minimum cytoplasmic antioxidant content, susceptible to lipid peroxidation resulted in impairment of sperm functions and decreased motility. Lipid peroxidation is one of the main factors of sperm damage during preservation. The prevention of sperm damage is necessary to maintain the sperm motility and sperm functions during preservation. Therefore, the preliminary study was conducted to observe the effect of $\mathrm{AX}$, a potent antioxidant supplementation on semen preservation of Karan Fries bulls at refrigerator temperature $\left(5^{\circ} \mathrm{C}\right)$.

\section{Materials and Methods}

The study was conducted on three $(n=3)$ adult healthy Karan Fries bulls (4-6 years) maintained at Artificial Breeding Research Centre (ABRC), Indian Council of Agricultural Research-National Dairy Research Institute (ICAR-NDRI), Karnal, Haryana. Six ejaculates from each bull were collected at weekly interval using artificial vagina $\left(42-45^{\circ} \mathrm{C}\right)$.

\section{Grading of semen}

A drop of fresh semen sample was placed on preheated $\left(37^{\circ} \mathrm{C}\right)$ glass slide; gently cover slip was placed upon the drop and observed under phase contrast microscope (Nikon eclipse E600, Tokyo, Japan) in low magnification (10x). The semen samples were graded on the basis of wave movement i. e., mass motility as 0 (waves not present, sperm cells immotile), + (waves not present, slight movement of sperm cells), ++ (barely distinguishable waves in motion), +++ (waves apparent, moderate motion) and ++++ (dark distinct waves in rapid motion). Semen samples having " +++ " or " ++++ " were selected for the study.

Dilution with Tris egg yolk citric acid fructose (TEYCAF) extender

The semen sample was extended in Tris egg yolk citric acid fructose (TEYCAF) in 1:10 ratio. The extended sample was split into control and AX supplementation (@2 $\mu \mathrm{M}$ ) and preserved at $5{ }^{\circ} \mathrm{C}$ for $0,24,48$ and 72 hours. 


\section{Progressive motility}

Five to six microliter of extended semen was placed in a pre-heated glass slide $\left(37{ }^{\circ} \mathrm{C}\right)$, cover slip was placed gently and observed under light microscope (40X, Labomad). Spermatozoa having forward movement were recorded as progressively motile.

\section{Non-eosinophilic spermatozoa}

Live spermatozoa were assessed by eosinnigrosin (EN) stain as suggested by Blom (15). EN stain was prepared by proper mixing of 1:5 ratio of eosin and nigrosin in $10 \mathrm{~mL}$ of $2.9 \%(\mathrm{pH} 6.8$ ) sodium citrate buffer with the help of a magnetic stirrer at $70-80{ }^{\circ} \mathrm{C}$ for 40 60 minutes. The content was filtered through filter paper and was kept at $4{ }^{\circ} \mathrm{C}$. Then $4 \mu \mathrm{L}$ of extended semen and $10 \mu \mathrm{L}$ of EN stain were placed on clean pre-warm glass slide, mixed properly and 5-8 $\mu \mathrm{L}$ of the mixture was drawn in a clean pre-warm glass slide, a very thin smear was made and air dried. The dead sperm stained pink (eosin) and partially stained sperm were also considered as dead while live sperm remained unstained (Figure 1). Two hundred spermatozoa were counted under oil immersion per slide from different fields.

\section{Catalase (CAT) and superoxidase dismutase (SOD) assay}

One $\mathrm{mL}$ of extended samples at different hours $(0,24,48$ and 72$)$ of interval were drawn into a new Eppendorf tube and centrifuge at $10000 \mathrm{rpm}$ for 10 minutes. The supernatant was drawn into a new sterile Eppendorf tube and kept at $-20{ }^{\circ} \mathrm{C}$ until the assay was done. Superoxide dismutase (MBSO40427, MyBioSource) and catalase (MBS039175, MyBioSource) were determined by bovine ELISA kits as per the manufacturer's protocol. The sensitivity of the assay kits was $2.0 \mathrm{U} / \mathrm{mL}$, and $1.0 \mathrm{U} / \mathrm{mL}$ for SOD and CAT, respectively. The optical density (OD) was recorded using a TECAN infinite PRO200 ELISA reader (TECAN Asia Pvt. Ltd., Singapore) at $450 \mathrm{~nm}$. The intraand inter assay coefficients of variation were $<10 \%$.

\section{Statistical analysis}

The data analysis was carried out by Prism 5 software, Student ' $t$ ' test was applied for analyzing the effect of $\mathrm{AX}$ on progressive motility, live spermatozoa, the concentration of catalase and superoxidase dismutase. Significant level at 5\% (0.05). The graphs were also prepared using Prism5 software.

\section{Results and Discussion}

The percentage of progressive motility was better $(\mathrm{p}<0.05)$ at $24(77.50 \pm 1.44$ vs. $72.5 \pm$ $2.5)$ and $48(77.50 \pm 1.44$ vs. $71.25 \pm 1.25)$ hours of preservation in AX supplemented samples than control samples at refrigerator

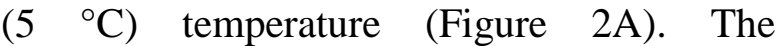
significant $(\mathrm{p}<0.05)$ effect was also observed in the percentage of live spermatozoa at 48 $(82.95 \pm 1.31$ vs. $78.57 \pm 0.70)$ and $72(80.92$ \pm 1.26 vs. $74.07 \pm 0.95$ ) hours of preservation in AX supplemented samples vs. control (Figure 2B). The concentration of catalase $(\mathrm{CAT})$ was decreased $(\mathrm{p}<0.05)$ in $\mathrm{AX}$ supplemented samples as compared to control at $48(7.38 \pm 1.43$ vs. $14.62 \pm 2.03)$ and 72 $(14.43 \pm 1.29$ vs. $19.45 \pm 2.82)$ hours (Figure 2C). However, superoxidase dismutase (SOD) concentration was decreased $(\mathrm{p}<0.05)$ only at 24 hours of preservation in AX supplementation as compared to control (Figure 2D).

Under stressful conditions the microalgae (Haematococcus pluvialis) synthesized AX for their survival. Astaxanthin (AX) is a powerful antioxidant synthesised abundance in Haematococcus pluvialis under stressful 
condition for their survival. It also present in fungi, complex plants, seafood, flamingos, and quail. It neutralizes free radicals or other oxidants very efficiently by either accepting or donating electrons without being destroyed or becoming a pro-oxidant in the process. AX predominantly marine origin demonstrated to be a potent antioxidant and anti-inflammatory in several studies (Fassett et al., 2011).

Fig.1 Live and dead spermatozoa under phase contrast microscope (100X)

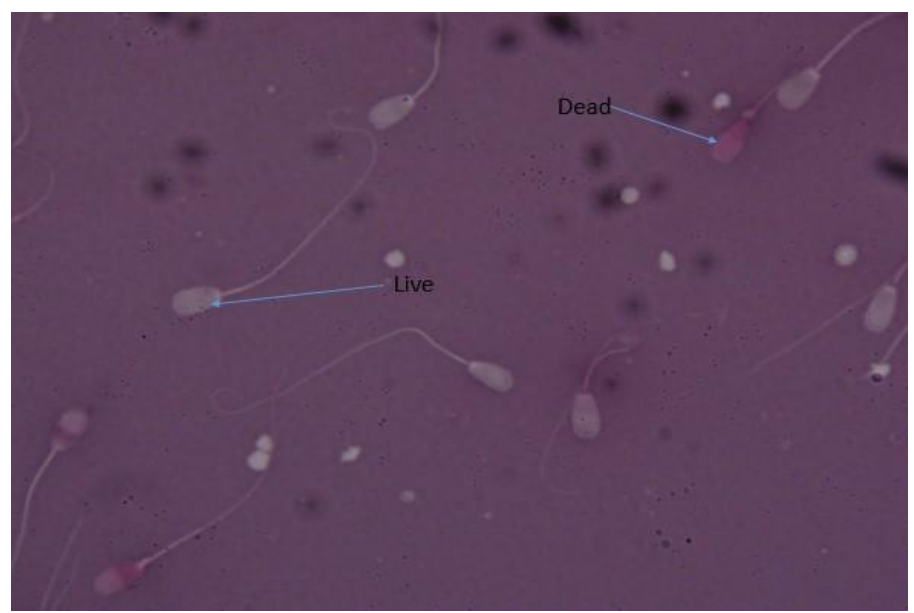

Fig.2 Effect of AX supplementation in extended semen of Karan Fires bulls during storage at 0, 24, 48 and 72 hours
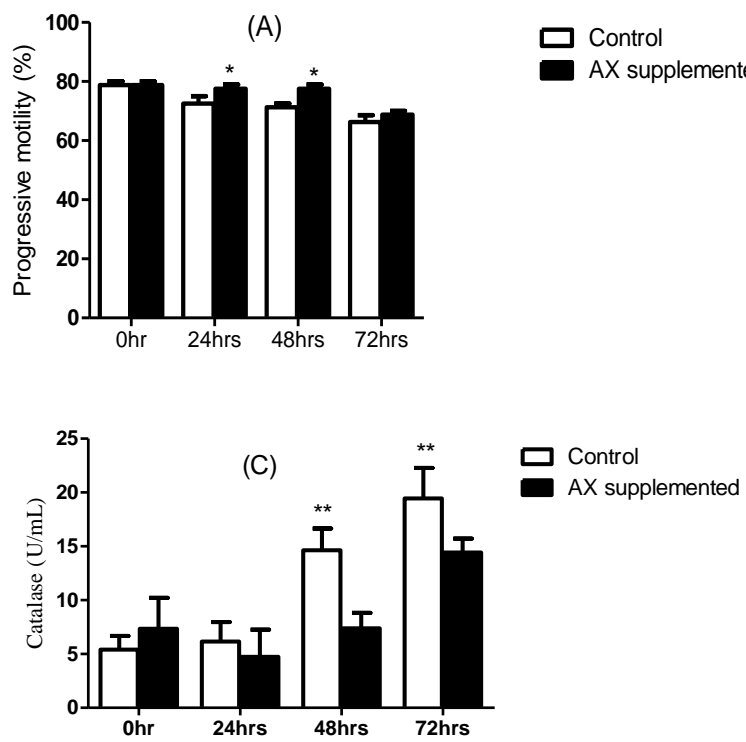

The present study showed the improvement of sperm quality during preservation at $5{ }^{\circ} \mathrm{C}$ (refrigerator temperature) using TEYCAF extender. The lower level of CAT and SOD
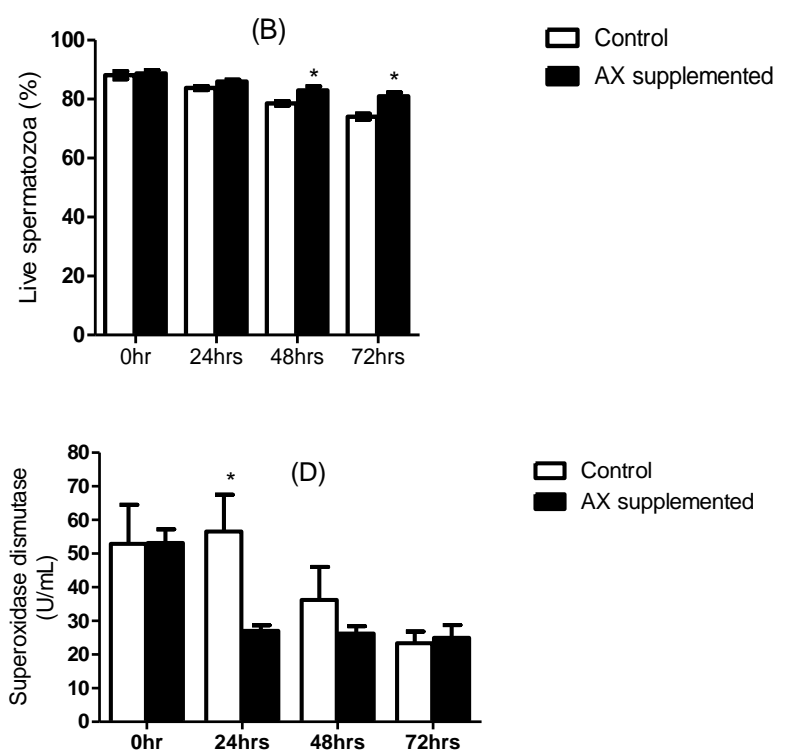

concentration in extended semen also indicates the antioxidant activity of AX. Similarly, Fang et al., (2015) and Farzan et al., (2014) also reported the improvement of 
sperm quality and reduction of malondialdehyde and ROS in AX supplementation during storage of ram and bull extended semen at $5{ }^{\circ} \mathrm{C}$ for 72 hours, respectively. $\mathrm{AX}$ is a lipid soluble pigment with potent inside and outside antioxidant properties gives overall protection (McNulty et al., 2007). Oral supplementation of AX has also been shown to have beneficial effects on sperm concentration, viability, normal sperm morphology, linear velocity and male fertility (Comhaire et al., 2005; Mortazavi et al., 2014). It is demonstrated (AX) of having a powerful scavenging capacity against free radicals (Pashkow et al., 2008). AX supplementation was found more effective when the sperm cells are more susceptible to oxidative attack (Pashkow et al., 2008; Salamon and Maxwel, 2000). Astaxanthin (AX) supplementation revealed the protective effects of spermatozoa during storage at refrigerator $\left(5^{\circ} \mathrm{C}\right)$ temperature.

\section{Acknowledgement}

The authors would like to thank the Director of ICAR-NDRI, Karnal for providing the facilities for this work and also to the Artificial Breeding Research Centre, ICARNDRI, Karnal for providing semen samples. The research work was funded by National Innovations on Climate Resilient Agriculture (NICRA), Indian Council of Agricultural Research, New Delhi.

\section{References}

Almbro, M., Dowling, D. K. and Simmons, L. W. 2011. Effects of vitamin E and betacarotene on sperm competitiveness. Ecol. Lett., 14: 891-895.

Blom, E. 1950. A rapid staining method to distinguish between live and dead spermatozoa. Anim. Breed Abst., 18: 1390.
Ciapara, H.I., Valenzuela, F.L. and Goycoolea, F.M. 2006. Astaxanthin: a review of its chemistry and applications. Critical Rev. Food Sci. Nutri., 46: 185196.

Guerin, M., Huntley, M.E. and Olaizola, M. 2003. Haematococcus astaxanthin: applications for human health and Nutrition. Trends in Biotechnol., 21: 210-216.

Comhaire, F.H., Garem, Y.E., Mahmoud, A., Eertmans, F. and Schoonjans, F. 2005. Combined conventional/ antioxidant "Astaxanthin" treatment for male infertility: a double blind, randomized trial. Asian J. Androl., 7: 257-262.

Eskenazi, B., Kidd, S.A., Marks, A.R., Sloter, E., Block, G. and Wyrobek, A.J. 2005. Antioxidant intake is associated with semen quality in healthy men. Hum. Reprod., 20: 1006-1012.

Fang, Y., Zhong, R., Chen, L., Feng, C., Sun, H. and Zhou, D. 2015. Effects of astaxanthin supplementation on the sperm quality and antioxidant capacity of ram semen during liquid storage. Small Ruminant Res., doi.org/10.1016/ j.smallrumres.2015.05. 016.

Farzan, M., Chamani, M. and Varnaseri, H. 2014. The antioxidant effect of astaxanthin on quantitative aheshnd qualitative parameters of bull sperm. Indian J. Fundamental and Appl. Life Sci., 4: 425-430.

Fassett, R.G. and Coombes, J.S. 2011. Astaxanthin: A Potential Therapeutic Agent in Cardiovascular Disease. Mar. Drugs, 9: 447-465.

Goto, S., Kogure, K., Abe, K., Kimata, Y., Kitahama, K., Yamashita, E. and Terada, H. 2001. Efficient radical trapping at the surface and inside the phospholipid membrane is responsible for highly potent antiperoxidative activity of the carotenoid astaxanthin. 
Biochim. Biophys. Acta., 1512: 251258.

Jyonouchi, H., Zhang, L., Gross, M. and Tomita, Y. 1994. Immunomodulating actions of carotenoids: enhancement of in vivo and in vitro antibody production to $\mathrm{T}$ dependent antigens. Nutr. Cancer, 21: 47-58.

McNulty, H.P., Byun, J., Lockwood, S.F., Jacob, R.F. and Mason, R.P. 2007. Differential effects of carotenoids on lipid peroxidation due to membrane interactions: X-ray diffraction analysis. Biochim. Biophys. Acta., 1768: 167174.

Mortazavi, M., Salehi, I., Alizadeh, Z., Vahabian, M. and Roushandeh, A. M. 2014. Protective effects of antioxidants on sperm parameters and seminiferous tubules epithelium in high fat-fed rats. J. Reprod. Infertil., 15: 22-28.

O'Connor, I. and O'Brien, N. 1998. Modulation of UVA light-induced oxidative stress by beta-carotene, lutein and astaxanthin in cultured fibroblasts. J. Dermatol. Sci., 16: 226-230.

Pashkow, F.J., Watumull, D.G. and Campbell, C.L. 2008. Astaxanthin: a novel potential treatment for oxidative stress and inflammation in cardiovascular disease. Am. J. Cardiol., 101: 58-68.

Salamon, S. and Maxwell, W.M. 2000. Storage of ram semen. Anim. Reprod. Sci., 62: 77-111.
Sariozkan, S., Bucak, M. N., Tuncer, P.B., Buyukleblebici, S. and Canturk, F. 2014. Influence of various antioxidants added to TCM-199 on postthaw bovine sperm parameters, DNA integrity and fertilizing ability. Cryobiol., 68: 129133.

Tripathi, D.N. and Jena, G.B. 2008. Astaxanthin inhibits cytotoxic and genotoxic effects of cyclo phosphamide in mice germ cells. Toxicol., 248: 96103.

Wayama, M., Ota, S., Matsuura, H., Nango, N., Hirata, A. and Kawano, S. 2013. Three-dimensional ultrastructural study of oil and astaxanthin accumulation during encystmentin thegreen alga Haematococcus pluvialis. PLoSONE, 8:e53618. doi:10.1371/ journal.pone. 0053618 .

Wolf, A. M., Asoh, S., Hiranuma, H., Ohsawa, I., Lio, K., Satou, A., Ishikura, M. and Ohta, S. 2010. Astaxanthin protects mitochondrial redox state and functional integrity against oxidative stress. J. Nutr. Biochem., 21: 381-389.

Yuan, J.P., Peng, J., Yin, K. and Wang, J.H. 2011. Potential health-promoting effects of astaxanthin: A high-value carotenoid mostly from microalgae. Mol. Nutr. Food Res., 55: 150-165.

\section{How to cite this article:}

Simson Soren, Sohan Vir Singh and Sunil Kumar. 2017. Effect of Astaxanthin Supplementation on Semen (Karan Fries Bulls) Storage at $5{ }^{\circ}$ C. Int.J.Curr.Microbiol.App.Sci. 6(5): 23-28. doi: http://dx.doi.org/10.20546/ijcmas.2017.605.003 